\title{
Pengaruh Kepedulian, Pengetahuan, Sikap, Inisiatif Pemerintah, Tekanan Teman Sebaya Dan Spiritualitas Terhadap Niat Beli Produk Ramah Lingkungan Di Banjarmasin
}

\section{Arafat Alhally}

Program Magister Manajemen, Universitas Lambung Mangkurat e-mail: alhallyarafat@gmail.com

\begin{abstract}
This study aims to find out and analyze the influence of environment concern, environment knowledge, environmental attitude, government initiative, peer pressure, and spirituality on the purchase intention of environmentally friendly products among consumers in Banjarmasin environment. This research is a research with quantitative approach. The research data are obtained using questionnaires which are distributed to 168 respondents in Banjarmasin. Structural Equation Model (SEM) is a method of data analysis used in this study. The result of this study indicate that environment concern, environment knowledge, environmental attitude, and spirituality have significance influence on purchase intention of environmentally friendly products. While, government initiative and peer pressure have no significance influence on the purchase intention of environmentally friendly products.
\end{abstract}

Keywords : concern, knowledge, spirituality, purchase intention, environmentally friendly products

\begin{abstract}
Abstrak
Penelitian ini bertujuan untuk mengetahui dan menganalisis pengaruh kepedulian, pengetahuan, sikap, inisiatif pemerintah, tekanan teman sebaya dan spiritualitas terhadap niat beli produk ramah lingkungan konsumen di Banjarmasin. Penelitian ini merupakan penelitian dengan pendekatan kuantitatif. Data penelitian diperoleh menggunakan kuesioner yang dibagikan kepada 168 orang responden di Banjarmasin. Structural Equation Model (SEM) merupakan metode analisis data yang digunakan pada penelitian ini. Hasil penelitian ini menunjukkan bahwa kepedulian, pengetahuan, sikap dan spiritualitas berpengaruh signifikan terhadap niat beli produk ramah lingkungan. Sedangkan inisiatif pemerintah dan tekanan teman sebaya tidak berpengaruh terhadap niat beli produk ramah lingkungan.
\end{abstract}

Kata kunci : kepedulian, pengetahuan, spiritualitas, niat beli, produk ramah lingkungan. 


\section{PENDAHULUAN}

Ekonomi mengalami pertumbuhan begitu pesat yang ditandai dengan jumlah konsumsi yang meningkat di segala penjuru dunia dalam beberapa dekade terakhir (Chen \& Chai, 2010). Kondisi ini turut menjadi penyebab pertumbuhan bisnis yang juga semakin pesat. Beragam keinginan konsumen terus terpenuhi dari pertumbuhan bisnis yang cepat ini. Secara eksternalitas, pertumbuhan bisnis menyebabkan berbagai permasalahan lingkungan. Banyak pihak yang telah memperhatikan hal ini dikarenakan sudah menjadi isu sosial (Mei et al., 2012). Seperti di China, pertumbuhan industri dihadapkan dengan masalah lingkungan yang cukup rumit. Dalam lingkup domestik, air tanah di $90 \%$ kota di China sudah terkontaminasi dan 54\% air sungai di Cina sudah tidak layak konsumsi. China juga merupakan sumber emisi sulfur dioxide terbesar di dunia (Marquis et al., 2011).

Semua aktivitas ekonomi pasti terkait dengan sumber daya alam dan lingkungan, contohnya adalah dalam proses pembuatan produk (material) hingga setelah produk tersebut digunakan yang pada akhirnya nanti akan menjadi limbah yang efeknya pasti berdampak pada alam atau lingkungan ini, oleh karena itu baik kita sebagai konsumen maupun produsen harus peduli dengan kelestarian lingkungan. Permasalahan lingkungan yang meningkat mengakibatkan praktek bisnis dan konsumen mulai peduli dengan permasalahan ini, konsep yang berkelanjutan (sustainable) merupakan salah satu konsep yang penting dibicarakan di era bisnis modern saat ini (Cherian \& Jacob, 2012).

Hal lain yang menyebabkan meningkatnya kepedulian lingkungan adalah karena beberapa media yang selalu membahas mengenai lingkungan, peraturan hukum yang ketat tentang lingkungan, isu lingkungan yang terus berkembang seperti semakin meningkatnya dampak dari pemanasan global, serta dampak industri, yang pada akhirnya mempengaruhi opini masyarakat. Ketatnya peraturan lingkungan dan pengaruh tekanan konsumen juga membuat para akademisi berfokus pada strategi manajemen yang berpengaruh pada lingkungan (Leonidou et al., 2010). Dibandingkan dengan konsumen di masa lalu, konsumen saat ini terdorong untuk menggunakan produk ramah lingkungan (Karmarkar \& Bollinger, 2014).

Produk ramah lingkungan dinyatakan sebagai produk yang tidak membahayakan bagi manusia dan lingkungannya, hemat energi, dan tidak menghasilkan sampah yang berlebihan (Kasali, 2005). Karakteristik dari produk ramah lingkungan yang dikemukakan oleh Pavan (2010) adalah dapat didaur ulang, tidak menghasilkan polusi terhadap lingkungan, bahan kimia yang terkandung dalam batas yang diperbolehkan.

Penelitian terdahulu menyatakan bahwa variabel yang mempengaruhi niat beli produk ramah lingkungan ialah pengetahuan, sikap, inisiatif pemerintah dan tekanan teman sebaya (Mei et al., 2012). Variabel lain yang mempengaruhi niat konsumen untuk membeli produk ramah lingkungan menurut Joshi (2016) ialah kepedulian dan spiritualitas.

Spiritualitas timbul dari pengembangan ritual keagamaan dan pembentukan masyarakat (King $\&$ Crowther, 2004). Antusias warga Banjarmasin dalam mengikuti kegamaan di tengah masyarakat begitu tinggi. Hal ini menunjukkan bahwa Banjarmasin adalah kota yang menjunjung tinggi nilai spiritualitas. Spiritualitas merupakan faktor penting dalam menentukan individu berperilaku termasuk perilaku konsumsi (Piedmont, 1999).

Pada umumnya banyak penelitian berkenaan dengan variabel-variabel yang mempengaruhi niat beli konsumen, namun semakin merebaknya isu lingkungan yang dikaitkan dengan kegiatan 
konsumen, membuat peneliti tertarik untuk memilih topik yang mengarah kepada perilaku konsumen yang ramah lingkungan dengan variabel independen kepedulian, pengetahuan, sikap, inisiatif pemerintah, tekanan teman sebaya, dan spiritualitas. Sedangkan variabel dependen ialah niat beli.

\section{TINJAUAN PUSTAKA}

\section{Produk Ramah Lingkungan}

Produk ramah lingkungan diartikan sebagai produk yang didesain dan diproses dengan serangkaian metode untuk memperkecil dampak yang berpotensi merusak lingkungan, baik dalam proses produksi, kegiatan distribusi dan saat produk itu dikonsumsi. Dengan kata lain, produk ramah lingkungan ialah produk yang mampu didaur ulang, tidak boros kemasan, tidak berkomposisi bahan yang beracun sehingga dapat mereduksi pencemaran terhadap lingkungan alam (Chen \& Chai, 2010). Contoh produk ramah lingkungan diantaranya, makanan organik, mobil hybrid, bahan bakar alternatif (Mun, 2014).

\section{Kepedulian}

Definisi kepedulian yang mengarah pada lingkungan ialah tingkatan sikap protektif terhadap lingkungan (Crosby, Gill \& Taylor, 1981). Kepedulian lingkungan didefinisikan oleh Dunlap \& Jones (2002) sebagai kesadaran masyarakat pada masalah lingkungan dan upaya untuk mengatasinya. Penelitian Kim \& Choi (2005) menunjukkan bahwa orang dengan kepedulian yang mendalam terhadap isu-isu lingkungan, mereka bersedia untuk membeli produk ramah lingkungan.

\section{Pengetahuan}

Pengetahuan terkait lingkungan diartikan sebagai serangkaian wawasan ekologis yang dimiliki oleh personal tentang beragam topik yang menyangkut lingkungan (Chen \& Chang, 2012). Pengetahuan dari setiap individu mengenai suatu isu lingkungan dapat memberikan efek signifikan terhadap rangkaian tindakan pengambilan keputusan mereka (Rashid, 2009). Laroche, Bergeron \& Forleo (2001) menyebutkan bahwa pengetahuan ialah konstruk yang signifikan. Konsumen dapat dipengaruhi oleh konstruk ini karena dengan pengetahuan, informasi dapat dikumpulkan dan diorganisasikan oleh konsumen. Konsumen dapat mengatur seberapa banyak informasi yang mereka gunakan untuk mengambil keputusan membeli dan dalam hal ketika ingin mengevaluasi produk tersebut.

\section{Sikap}

Sikap dapat didefinisikan sebagai evaluasi yang diinginkan atau tidak diinginkan (Ajzen, 1991). Rashid (2009) mengartikan sikap yang mengacu pada lingkungan sebagai pembelajaran untuk menanggapinya secara konsisten dengan melihat untung atau tidaknya terhadap lingkungan. Sementara Schultz, Shriver, Tabanico \& Khazian (2004) mendefinisikan sikap lingkungan sebagai kumpulan dari kepercayaan, pengaruh, niat perilaku seseorang berpegang teguh pada kegiatan atau isu terkait lingkungan. Sikap lingkungan menurut Lee (2008) berdasarkan penilaian kognitif individu dari nilai pelestarian lingkungan.

\section{Inisiatif Pemerintah}

Inisiatif pemerintah merujuk kepada inisiatif yang diimplementasikan pemerintah atau dorongan yang dilakukan oleh pemerintah (Diekmeyer dalam Mei et al., 2012). Sebagai figur yang baik kepada warga yang dipimpinnya, pemerintah harus merealisasikan ucapannya dalam membentuk 
dan menerapkan program yang keberlanjutan berkenaan dengan lingkungan hidup. Program berkelanjutan tersebut harus dipromosikan kepada komunitas agar kesadaran masyarakat semakin meningkat, serta menegakkan aturan tentang lingkungan (Mei et al., 2012).

\section{Tekanan Teman Sebaya}

Tekanan dari teman sebaya mengarah kepada tekanan psikologis yang dirasakan setiap individu ketika perbuatannya dibandingkan dengan temannya yang lain (Cohan dalam Mei et al., 2012). Informasi yang disediakan kepada individu tidak cukup untuk mengubah perilakunya. Perubahan pergeseran perilaku dapat disebakan adanya perasaan bersalah terhadap teman ketika tidak berkenan melakukan apa yang diminta oleh temannya tersebut (Mei et al., 2012).

\section{Spiritualitas}

Spiritualitas didefinisikan sebagai sebuah keterhubungan dengan Tuhan, yang menimbulkan suatu makna, tujuan dan misi dalam hidup (Ratnakar \& Nair, 2012). Spiritualitas mengacu pada pencarian yang suci melalui cara yang ditentukan untuk melihat dan menjalani kehidupan. Spiritualitas memiliki motivasi pengaruh dalam sistem psikologis manusia. Pada praktiknya sebagai salah satu aspek nilai pribadi, spiritualitas berkaitan dengan kognisi dan perilaku etis. Hal ini merupakan faktor penting dalam menentukan bagaimana individu berperilaku termasuk perilaku konsumsi (Piedmont, 1999).
Niat Beli Produk Ramah Lingkungan

Niat beli produk ramah lingkungan ialah tindakan atau perbuatan yang secara khusus dilakukan oleh seseorang untuk memperlihatkan bahwa orang tersebut mempunyai kepedulian terhadap lingkungan (Ling, 2015). Pengertian lain dari Rashid (2009), niat beli produk ramah lingkungan berarti kemauan seseorang untuk mempunyai preferensi produk dengan catatan produk tersebut mempunyai fitur ramah lingkungan sebagai bahan pemikiran untuk dibandingkan dengan produk umum lainnya. Studi telah memperlihatkan bahwa intensi atau niat ialah prediktor yang kuat dari perilaku seseorang dalam penentuan keputusan membeli produk ramah lingkungan (Chen \& Chai, 2010).

\section{Hipotesis Penelitian}

H1: Kepedulian berpengaruh terhadap niat konsumen untuk membeli produk ramah lingkungan

H2: Pengetahuan berpengaruh terhadap niat konsumen untuk membeli produk ramah lingkungan

H3: Sikap berpengaruh terhadap niat konsumen untuk membeli produk ramah lingkungan

H4: Inisiatif pemerintah berpengaruh terhadap niat konsumen untuk membeli produk ramah lingkungan

H5: Tekanan teman sebaya berpengaruh terhadap niat konsumen untuk membeli produk ramah lingkungan

H6 : Spiritualitas berpengaruh terhadap niat konsumen untuk membeli produk ramah lingkungan 


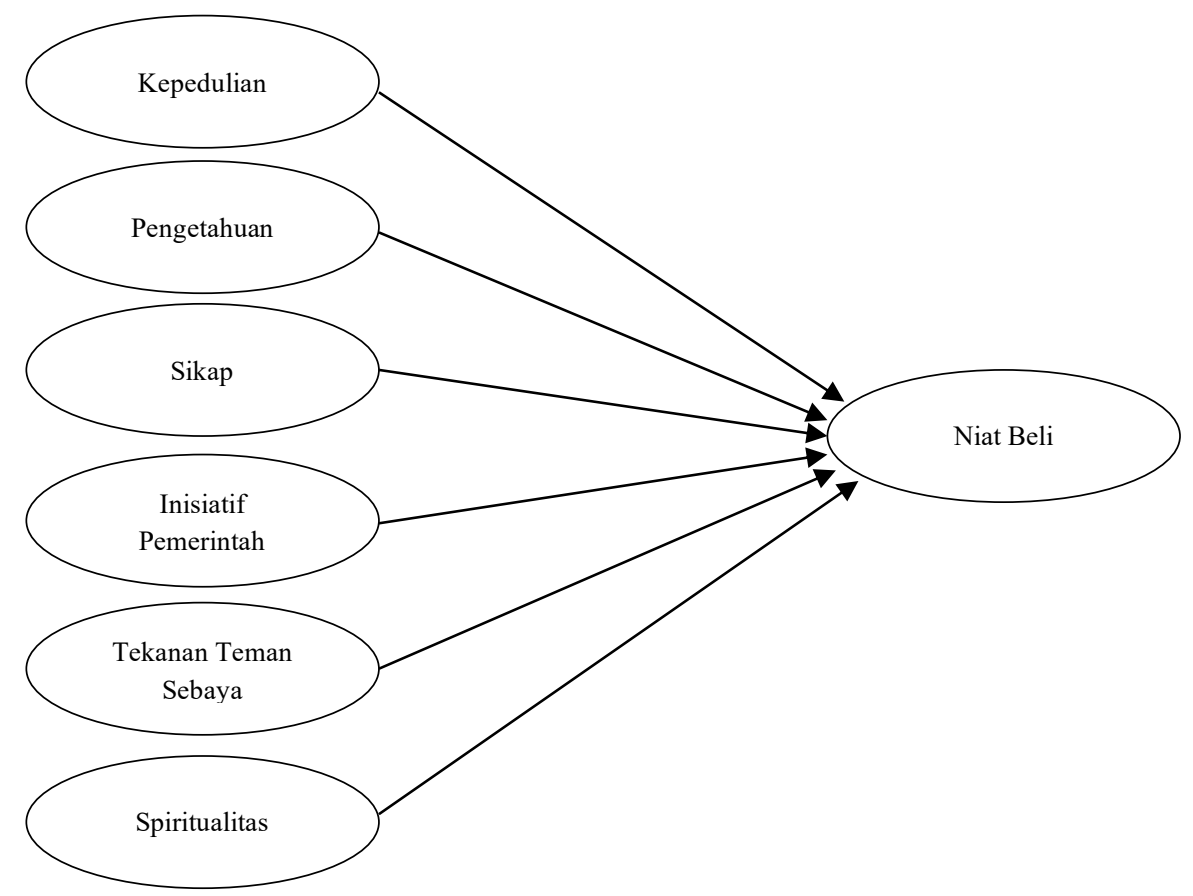

Gambar 1. Kerangka Penelitian

Sumber : diolah penulis, 2017

\section{METODE PENELITIAN}

\section{Jenis Penelitian}

Penelitian ini bersifat kuantitatif yang memakai pendekatan survei, yakni sampel diambil secara langsung dari populasi.

\section{Populasi dan Ukuran Sampel Penelitan}

Jumlah konsumen di Banjarmasin yang telah melakukan transaksi pembelian produk ramah lingkungan, sejauh ini belum ada data akurat yang menyatakannya. Populasi dalam penelitian ini ialah konsumen Banjarmasin.

Sesuai dengan pedoman untuk persyaratan ukuran sampel dalam menggunakan SEM dengan teknik maximum likelihood estimation di atas, maka jumlah minimum sampel yang harus dipenuhi dalam penelitian ini sebanyak 100-200 responden (Ghozali, 2011). Dalam penelitian ini diambil sebanyak 168 sampel.

\section{Teknik Pengumpulan Data}

Pengumpulan data pada penelitian ini, peneliti memakai teknik purposive sampling yaitu pengambilan sampel yang dipilih dengan menggunakan kriteria khusus terhadap sampel. Kriteria yang digunakan adalah responden harus berusia minimal 18 tahun, mengetahui tentang produk ramah lingkungan, berdomisili di Banjarmasin.

Metode Analisis Data

Metode Stuctural Equation Model (SEM) digunakan dalam analisis data dilakukan. Perangkat lunak yang dipakai untuk analisis struktural ialah AMOS 21.

\section{HASIL DAN PEMBAHASAN}

Hasil

Data responden yang terkumpul sebanyak 168. Karakteristik responden pada penelitian ini berdasarkan jenis kelamin, usia, pendidikan, jenis pekerjaan dan pendapatan per bulan yang ditampilkan dalam Tabel 1 .

Berdasarkan Tabel 1 dapat dilihat hal-hal sebagai berikut :

a. Karakteristik responden berdasarkan jenis kelamin, yaitu responden wanita lebih banyak daripada pria. Ini menandakan 
wanita lebih banyak mengetahui tentang produk ramah lingkungan, karena hal tersebut menjadi kriteria yang harus dipenuhi menjadi responden.

b. Karakteristik responden berdasarkan usia, yaitu responden yang berusia 26-35 tahun merupakan usia dominan, ini dikarenakan usia tersebut adalah usia produktif yang memiliki penghasilan. Disusul dengan responden yang berusia 18-25 tahun.

c. Karakteristik responden berdasarkan pendidikan, yaitu responden yang berpendidikan SD sederajat hingga S3 semuanya terwakili dan yang paling dominan adalah responden berpendidikan $\mathrm{S} 1$, karena pendidikan yang cukup tinggi akan lebih mengetahui tentang produk ramah lingkungan. d. Karakteristik responden berdasarkan pendidikan, yaitu responden pegawai swasta menempati urutan pertama, dan disusul oleh responden PNS/ASN. Kemungkinan pegawai swasta dan PNS/ASN memiliki penghasilan yang lebih tinggi sehingga tidak ragu untuk membeli sebuah produk.

e. Karakteristik responden berdasarkan pendapatan per bulan, yaitu responden berpendapatan Rp. 3.000.000 - Rp. 4.999.000 paling dominan, artinya reponden banyak memiliki penghasilan di atas upah minimum yang memungkinkan mereka untuk berniat membeli produk ramah lingkungan karena harganya relatif lebih mahal jika dibandingkan dengan produk konvensional yang sejenis.

Tabel 1. Karakteristik Responden

\begin{tabular}{|c|c|c|}
\hline Jenis Kelamin & Jumlah & Persentase \\
\hline Pria & 54 & $32 \%$ \\
\hline Wanita & 114 & $68 \%$ \\
\hline Usia & Jumlah & Persentase \\
\hline $18-25$ tahun & 68 & $40 \%$ \\
\hline $26-35$ tahun & 72 & $43 \%$ \\
\hline $36-45$ tahun & 14 & $8 \%$ \\
\hline $46-55$ tahun & 10 & $6 \%$ \\
\hline $56-65$ tahun & 2 & $1 \%$ \\
\hline$\geq 65$ tahun & 2 & $1 \%$ \\
\hline Pendidikan & Jumlah & Persentase \\
\hline SD sederajat & 2 & $1 \%$ \\
\hline SMP sederajat & 2 & $1 \%$ \\
\hline SMA sederajat & 52 & $31 \%$ \\
\hline Diploma & 14 & $8 \%$ \\
\hline Strata 1 & 68 & $40 \%$ \\
\hline Strata 2 & 28 & $17 \%$ \\
\hline Strata 3 & 2 & $1 \%$ \\
\hline Jenis Pekerjaan & Jumlah & Persentase \\
\hline Mahasiswa & 32 & $19 \%$ \\
\hline PNS/ASN & 34 & $20 \%$ \\
\hline TNI/POLRI & 12 & $7 \%$ \\
\hline Pegawai BUMN & 18 & $11 \%$ \\
\hline Pegawai Swasta & 50 & $30 \%$ \\
\hline Wiraswasta & 4 & $2 \%$ \\
\hline Lainnya & 18 & $11 \%$ \\
\hline Pendapatan per bulan & Jumlah & Persentase \\
\hline$<$ Rp. 1.000 .000 & 26 & $15 \%$ \\
\hline Rp. $1.000 .000-$ Rp. 2.999 .000 & 56 & $33 \%$ \\
\hline Rp. $3.000 .000-$ Rp. 4.999 .000 & 66 & $39 \%$ \\
\hline$\geq$ Rp. 5.000 .000 & 20 & $12 \%$ \\
\hline
\end{tabular}

Sumber : Data diolah, 2017 
Tabel 2. Hasil Pengujian Validitas dan Reliabilitas Konstruk

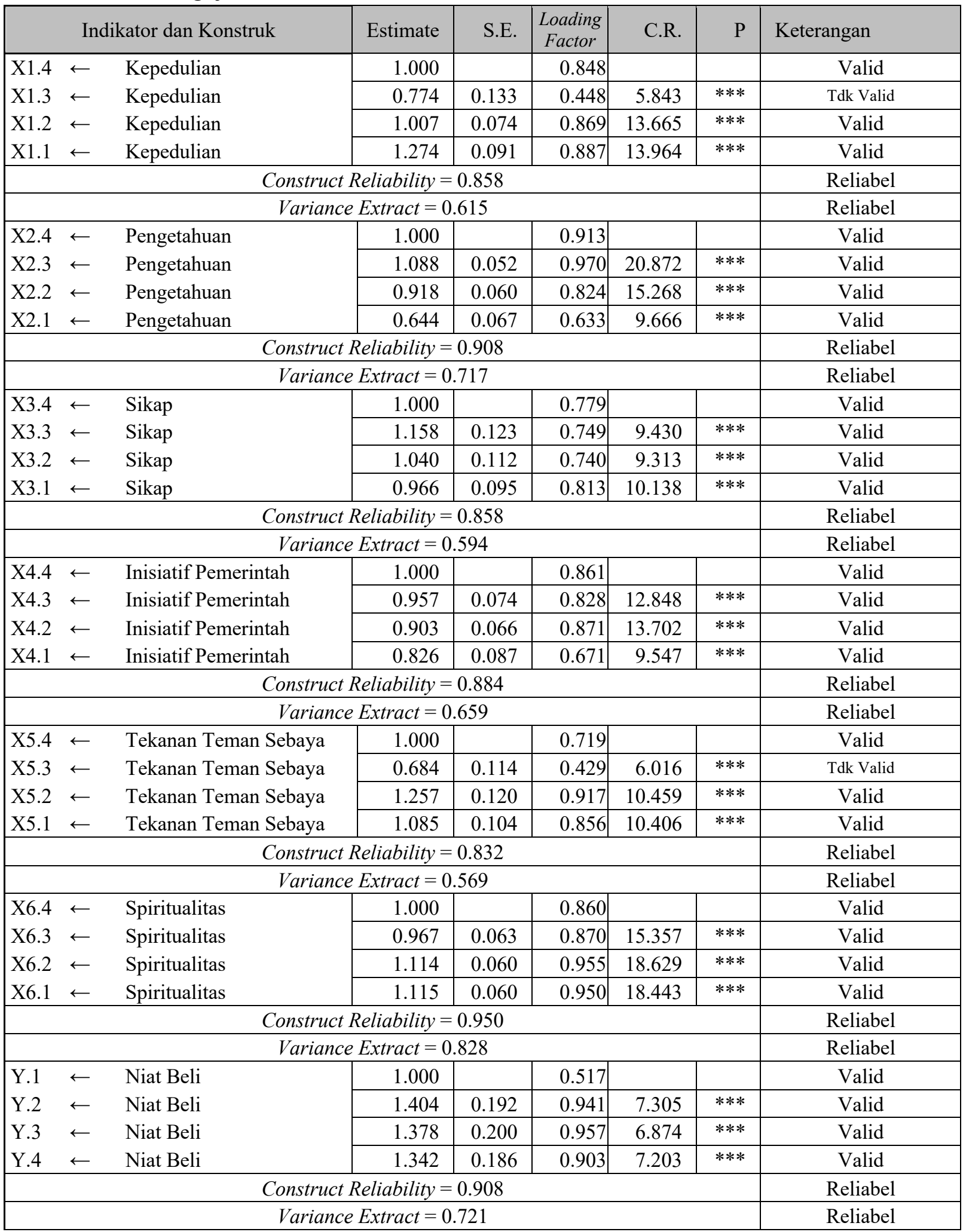

Sumber : Data diolah (2017) 
Tabel 3. Hasil Pengujian Hipotesis

\begin{tabular}{|lll|rrrrrl|}
\hline \multicolumn{2}{r|}{ Hipotesis } & & Estimate & S.E. & C.R. & Standardized & P & Keterangan \\
\hline Kepedulian & $\rightarrow$ & Niat Beli & 0.247 & 0.069 & 3.600 & 0.363 & $* * *$ & Signifikan \\
Pengetahuan & $\rightarrow$ & Niat Beli & 0.059 & 0.029 & 2.051 & 0.096 & 0.040 & Signifikan \\
Sikap & $\rightarrow$ & Niat Beli & 0.185 & 0.062 & 2.976 & 0.300 & 0.003 & Signifikan \\
Inisiatif Pemerintah & $\rightarrow$ & Niat Beli & 0.050 & 0.036 & 1.387 & 0.084 & 0.166 & Tidak Signifikan \\
Tekanan Teman Sebaya & $\rightarrow$ & Niat Beli & 0.014 & 0.054 & 0.269 & 0.013 & 0.788 & Tidak Signifikan \\
Spiritualitas & $\rightarrow$ & Niat Beli & 0.151 & 0.074 & 2.050 & 0.202 & 0.040 & Signifikan \\
\hline
\end{tabular}

Sumber : Data diolah (2017)

Pengujian hipotesis dilakukan setelah output dari model yang digunakan telah melalui validasi dan reliabilitas setiap konstruk yang tersaji pada tabel 2, kemudian melalui proses modifikasi kesesuaian. Dalam menguji hipotesis akan menghasilkan koefisien regresi yang dilihat signifikansinya seperti tersaji pada tabel 3 .

Dari tabel 3 terlihat bahwa pengaruh antara kepedulian terhadap niat beli produk ramah lingkungan diindikasikan dengan nilai CR sebesar 3,600 $>2$ dan nilai $\mathrm{P} * * *<$ 0,05 . Dengan demikian H1 pada penelitian ini diterima dan signifikan.

Dari tabel 3 terlihat bahwa pengaruh antara pengetahuan terhadap niat beli produk ramah lingkungan diindikasikan dengan nilai CR sebesar 2,051 $>2$ dan nilai P $0,040<0,05$. Dengan demikian H2 pada penelitian ini diterima dan signifikan.

Dari tabel 3 terlihat bahwa pengaruh antara sikap terhadap niat beli produk ramah lingkungan diindikasikan dengan nilai $\mathrm{CR}$ sebesar 2,976 > 2 dan nilai P sebesar 0,003 $<0,05$. Dengan demikian H3 pada penelitian ini diterima dan signifikan.

Dari tabel 3 terlihat bahwa pengaruh antara inisiatif pemerintah terhadap niat beli produk ramah lingkungan diindikasikan dengan nilai CR sebesar $1,387<2$ dan nilai $\mathrm{P}$ sebesar 0,084 >0,05. Dengan demikian H4 pada penelitian ini ditolak

Dari tabel 3 terlihat bahwa pengaruh antara tekanan teman sebaya terhadap niat beli produk ramah lingkungan diindikasikan dengan nilai $\mathrm{CR}$ sebesar $1,387<2$ dan nilai $\mathrm{P}$ sebesar 0,166 $>0,05$. Dengan demikian H5 pada penelitian ini ditolak.

Dari tabel 3 terlihat bahwa pengaruh antara spiritualitas terhadap niat beli produk ramah lingkungan diindikasikan dengan nilai $C R$ sebesar 2,050 $>2$ dan nilai $P$ sebesar $0,040<0,05$. Dengan demikian H6 pada penelitian ini diterima dan signifikan.

\section{Pembahasan}

Pengaruh Kepedulian Terhadap Niat Beli Produk Ramah Lingkungan

Kepedulian lingkungan dari konsumen berdasarkan hasil penelitian ini mempunyai pengaruh positif dan signifikan terhadap niat konsumen di Banjarmasin untuk membeli produk ramah lingkungan. Temuan ini berarti bahwa kepedulian lingkungan bagi responden yang mengetahui tentang produk ramah lingkungan menjadi variabel yang penting dalam menumbuhkan niat untuk membeli produk yang ramah lingkungan. Hal ini menandakan produkproduk yang ramah lingkungan akan banyak dibeli oleh konsumen jika konsumen tersebut mempunyai kepedulian lingkungan sebagai salah satu upaya untuk memperkecil efek buruk pada lingkungan yang diakibatkan oleh produk-produk sejenis yang non ramah lingkungan.

Hasil penelitian ini turut mendukung penelitian yang telah dilakukan oleh Joshi (2016) dan Ling (2015) bahwa ada pengaruh kepedulian lingkungan terhadap niat beli 
produk ramah lingkungan. Kepedulian lingkungan merupakan bagian dari konsep diri sebagai pengaruh internal. Kepedulian adalah bentuk dari kepribadian yang menyatukan konsep diri dan bermuara pada kemampuannya dalam mempengaruhi niat membeli produk ramah lingkungan.

Joshi (2016) mengemukakan bahwa dengan kepedulian lingkungan yang dimiliki konsumen, dampak lingkungan yang ditimbulkan menjadi kecil dengan melakukan pembelian produk ramah lingkungan. Merujuk pada pendapat Joshi (2016) tersebut dan sejalan dengan temuan penelitian, kepedulian lingkungan memberikan keistimewaan lebih bagi produsen produk yang tergolong ramah lingkungan dan lingkungan itu sendiri.

\section{Pengaruh Pengetahuan Terhadap Niat Beli Produk Ramah Lingkungan}

Pengetahuan lingkungan dari konsumen berdasarkan hasil penelitian ini mempunyai pengaruh positif dan signifikan terhadap niat konsumen di Banjarmasin untuk membeli produk ramah lingkungan. Temuan ini memperlihatkan bahwa pengetahuan berkaitan lingkungan bagi responden juga menjadi variabel yang penting untuk menumbuhkan niat beli produk yang tergolong ramah lingkungan.

Joshi (2016) mengemukakan bahwa pengetahuan berkaitan dengan lingkungan yang dimiliki konsumen merefleksikan pengetahuan tentang masalah lingkungan dan berusaha memecahkan masalah tersebut. Merujuk pada pendapat Joshi (2016) tersebut dan sejalan dengan temuan penelitian, pemasar produk ramah lingkungan perlu melakukan peningkatan pengetahuan konsumen misalnya mengadakan suatu forum bertema lingkungan dengan membawa branding produk sebagai salah satu solusi melindungi lingkungan. Peningkatan pengetahuan juga bisa dilakukan oleh pemasar dengan menulis artikel-artikel yang berhubungan dengan lingkungan di website produk atau media sosial.

\section{Pengaruh Sikap Terhadap Niat Beli Produk} Ramah Lingkungan

Sikap lingkungan dari konsumen berdasarkan hasil penelitian ini mempunyai pengaruh positif dan signifikan terhadap niat konsumen di Banjarmasin untuk membeli produk ramah lingkungan. Sikap lingkungan ialah pandangan positif atau negatif terhadap lingkungan yang terwujud dari unsur keyakinan dan unsur evaluasi tentang lingkungan. Hasil penelitian ini mendukung penelitian yang dilakukan oleh Mei et al (2012); Usmani et al (2015); Ling (2015) bahwa ada pengaruh sikap lingkungan terhadap niat beli produk yang tergolong ramah lingkungan.

Usmani et al (2015) mengemukakan bahwa sikap lingkungan membangun kesadaran dalam menyikapi permasalahan lingkungan yang pada akhirnya mempengaruhi niat membeli produk ramah lingkungan. Merujuk pada pendapat Usmani et al (2015) tersebut dan sejalan dengan temuan penelitian, pemasar perlu mendesain strategi pemasaran yang selaras untuk konsumen di Banjarmasin yang mempunyai kesadaran sikap bahwa betapa berharganya kelestarian lingkungan sekitar. Kesadaran sikap yang ditanamkan oleh konsumen Banjarmasin merupakan hal yang berpotensi untuk terus disempurnakan dengan mengikutsertakan mereka pada kegiatankegiatan yang berkaitan dengan perlindungan dan kelestarian lingkungan. 
Pengaruh Inisiatif Pemerintah Terhadap Niat Beli Produk Ramah Lingkungan

Inisiatif pemerintah berdasarkan hasil penelitian ini tidak memiliki pengaruh terhadap niat konsumen di Banjarmasin untuk membeli produk ramah lingkungan. Hasil penelitian ini dari variabel inisiatif pemerintah tidak mendukung penelitian yang dilakukan oleh Mei et al (2012); Usmani et al (2015); Ling (2015). Dengan demikian inisiatif pemerintah secara empiris tidak memperkuat penelitian sebelumnya. Inisiatif pemerintah merupakan faktor eksternal yang tidak sekuat faktor internal dalam mempengaruhi konsumen. Artinya hal-hal yang dilakukan pemerintah untuk lingkungan tidak menumbuhkan niat membeli produk ramah lingkungan. Hasil yang didapat tidak signifikan ini bisa disebabkan karena masyarakat tidak begitu merasakan kebijakan pemerintah dalam mengubah pola hidup ramah lingkungan, selain itu pengawasan terhadap penegakkan peraturan mengenai lingkungan masih terbilang lemah.

Tripathi et al (2016) dalam penelitiannya mengemukakan bahwa inisiatif pemerintah tidak mempunyai pengaruh terhadap niat beli produk ramah lingkungan. Temuan tersebut memperlihatkan persepsi konsumen terhadap pemerintah dalam mempengaruhi masyarakat untuk membeli produk ramah lingkungan tidaklah berhasil. Merujuk pada pendapat Tripathi et al (2016) tersebut dan sejalan dengan temuan penelitian ini, pemerintah setempat perlu mengevaluasi program-program pemerintah berkaitan lingkungan karena inisiasi yang dilakukan belum mampu maksimal menimbulkan niat konsumen membeli produk yang tergolong ramah lingkungan.
Pengaruh Tekanan Teman Sebaya Terhadap Niat Beli Produk Ramah Lingkungan

Tekanan teman sebaya dari konsumen berdasarkan hasil penelitian ini tidak memiliki pengaruh terhadap niat konsumen di Banjarmasin untuk membeli produk ramah lingkungan. Hasil penelitian ini dilihat dari variabel tekanan teman sebaya berarti tidak mendukung penelitian yang dilakukan oleh Mei et al (2012); Usmani et al (2015). Dengan demikian pengaruh teman secara empiris tidak memperkuat penelitian sebelumnya. Dalam kehidupan sosial, teman sebenarnya merupakan bagian yang terbilang penting saat usia remaja maupun dewasa. Tekanan teman sebaya adalah pengaruh eksternal yang dalam penelitian ini ternyata tidak cukup penting bagi konsumen untuk memunculkan niat dalam membeli produk ramah lingkungan. Hasil yang tidak signifikan disebabkan karena faktor yang paling penting dalam niat seseorang adalah faktor yang berasal dari dalam dirinya, jika pendiriannya sudah kuat terhadap lingkungan, maka pengaruh teman hanya sebatas sebagai pendukung namun bukan menjadi pengaruh yang utama.

Hasil analisis menggunakan indikator dari pengaruh teman menunjukkan tidak ada pengaruhnya terhadap niat beli. Temuan ini mengartikan bahwa konsumen yang telibat sebagai responden memiliki konsep diri yang sangat kuat sehingga pengaruh luar seperti halnya pengaruh teman sebaya bukan menjadi penggerak seseorang untuk berniat melakukan konsumsi produk ramah lingkungan. Selain itu, budaya untuk mengajak teman di Banjarmasin dalam melakukan pembelian produk yang tergolong ramah lingkungan jarang diterapkan. 
Ling (2015) dalam penelitiannya mengemukakan bahwa pengaruh teman tidak mempunyai pengaruh yang signifikan terhadap niat beli produk ramah lingkungan. Temuan ini menunjukkan kurang maksimalnya pengaruh teman terhadap niat beli produk ramah lingkungan. Karena berniat membeli sebuah produk yang ramah lingkungan akan lebih mudah bagi konsumen dengan dipengaruhi oleh faktor dalam dirinya. Artinya pihak pemasar harus lebih intensif dalam melakukan strategi pemasaran yang langsung mempengaruhi faktor internal dalam diri konsumen Banjarmasin seperti mengadakan kampanye cinta lingkungan dan alam.

\section{Pengaruh Spiritualitas Terhadap Niat Beli} Produk Ramah Lingkungan

Spiritualitas dari konsumen berdasarkan hasil penelitian ini memiliki pengaruh positif dan signifikan terhadap niat konsumen di Banjarmasin untuk membeli produk ramah lingkungan. Spiritualitas menjadi variabel yang juga berpengaruh secara signifikan seperti kepedulian, pengetahuan dan sikap lingkungan. Di dalam agama sangat dianjurkan untuk menjaga lingkungan, sehingga tidak heran konsumen akan berniat membeli produk yang tergolong ramah lingkungan dengan landasan agama sebagai faktor penentu.

Hasil ini dapat dikatakan mendukung penelitian yang dilakukan oleh Chairy (2012); Joshi (2016) bahwa ada pengaruh spiritualitas terhadap niat beli produk ramah lingkungan. Chairy (2016) dalam penelitiannya menyimpulkan bahwa spiritualitas memberikan hasil empiris yang menjadi nilai personal dalam menumbuhkan niat beli produk ramah lingkungan. Merujuk pada pendapat Chairy (2012) tersebut dan sejalan dengan temuan penelitian, para pemasar dapat bekerjasama dengan pembuat kebijakan agar mengatur kegiatan yang dapat menambah spiritualitas, sehingga dengan karakter masyarakat Banjarmasin yang menjunjung tinggi nilai spiritualitas, Banjarmasin menjadi pasar yang potensial untuk perkembangan produk yang tergolong ramah lingkungan.

\section{KESIMPULAN DAN SARAN}

\section{Kesimpulan}

Variabel kepedulian, pengetahuan, sikap dan spiritualitas dari konsumen Banjarmasin memiliki pengaruh signifikan terhadap niat beli produk ramah lingkungan. Sedangkan variabel inisiatif pemerintah dan tekanan teman sebaya dari konsumen Banjarmasin tidak memiliki pengaruh signifikan terhadap niat beli produk ramah lingkungan.

\section{Saran}

Produsen produk yang tergolong ramah lingkungan dapat melakukan hal terkait dengan penelitian antara lain, meningkatkan kepedulian konsumen akan lingkungan melalui kampanye dan iklan. Materi kampanye dan iklan berupa gambaran akibat penurunan kualitas lingkungan dan berusaha menekankan bahwa konsumen mengutamakan perhatiannya kepada lingkungan serta memberikan solusi yang tepat untuk meningkatkan kualitas lingkungan melalui cara konsumsi yang ramah lingkungan. Produsen produk ramah lingkungan harus bisa mempublikasikan bahwa produk yang dihasilkan tidak memperparah kondisi bumi seperti isu lingkungan pemanasan global yang terjadi. Karena konsumen memiliki pengetahuan tentang lingkungan, pada kemasan produk juga perlu dicantumkan bahwa produk yang dimaksud mengandung bahan-bahan atau komposisi yang aman bagi lingkungan. Meningkatkan sikap konsumen akan 
pentingnya lingkungan seperti pengurangan konsumsi plastik. Pemasar mendukung gerakan untuk menekan penggunaan kantong plastik yang saat ini gencar diterapkan di berbaga kota. Spritualitas yang dimiliki oleh konsumen harus didukung dengan cara mensponsori kegiatan-kegiatan yang bersifat keagamaan.

Agenda penelitian mendatang hendaknya peneliti fokus pada satu jenis produk ramah lingkungan, misalnya jenis lampu LED yang ramah lingkungan atau produk pangan organik. Pada penelitian yang akan datang bisa ditambahkan beberapa variabel dan atau indikator terkini, untuk menyempurnakan model yang dipakai pada penelitian ini, misalnya variabel promosi yang menonjolkan fitur ramah lingkungan, variabel citra diri dan berbagai variabel lainnya. Dengan demikian, hasil penelitian selanjutnya menjadi lebih sempurna dan lebih berkembang.

\section{DAFTAR PUSTAKA}

Ajzen I. (1991). The theory of planned behavior: Organizational Behavior Human Decision Process, 50:179-211.

Chairy. (2012). Spirituality, Self Transcendence, and Green Purchase Intention in College Students. Procedia Social and Behavioral Sciences, 57, 243 246.

Chen, T.B., \& Chai, L. T. (2010). Attitude towards the Environment and Green Products Consumers Perspective. Management Science and Engineering, 2739.

Chen,Y.S., \& Chang, C.H. (2012). Enhance Green Purchasae Intentions. Management Decision, 50, 502-520.

Cherian, J. \& Jacob, J. (2012). Green Marketing: A Study of Consumers' Attitude towards Environment Friendly Products. Asian Social Science; 8(12).
Crosby, L. A., Gill, J. D. \& Taylor, J.R. (1981). Consumer-voter behavior in the passage of the Michigan container law. Journal of Marketing, 45(2), 19-32.

Dunlap, R. E. \& Jones, R. E. 2002. Environmental concern: conceptual and measurement issues. In Handbook of Environmental Sociology, Westport,CN: Greenwood Press.

Ghozali, I. 2011. Model Persamaan Struktural: Konsep dan Aplikasi dengan Program AMOS 19.0 Edisi 4, BP Universitas Diponegoro, Semarang.

Joshi, Y. (2016), Investigating the Influence of Spirituality, Environmental Concern and Ecological Knowledge on Consumers' Green Purchase Intention. Purusharta Journal, 9(2), 54-61.

Kasali, R. 2005. Sembilan Fenomena Bisnis, Manajemen Student Society, FEUI official Site

Karmarkar, U. R., \& Bollinger, B. (2014). BYOB: How Bringing your Own Shopping Bag Leads to Treating Yourself, and the Environment. Boston, MA: Harvard Business School Press.

Kim, Y., \& Choi, S. M. (2005). Antecedents of green purchase behavior: An examination of collectivism, environmental concern, and PCE. Advances in Consumer Research, 32, 592-599.

King JE \& Crowther MR. (2004). The measurement of religiosity and spirituality. Journal of Organizational Change Management. 17, 83-101.

Laroche,M., Bergeron, J., Forleo, G.B. (2001). Targeting Consumers Who are Willing to Pay More for Environmentally Friendly Products. Journal of Consumer Marketing, 18(6), 503-520.

Lee, K. (2008). Opportunities for green marketing: Young consumers. Marketing Intelligence \& Planning, 26(6), 573-586.

Leonidou, C.L, Leonidou, C.N, \& Kvasova, O. (2010). Antecedents and Outcomes of 
Consumer Environmentally Friendly Attitudes and Behaviour. Journal of Marketing Management, 26, 1319-1344.

Ling, C.F. (2015). Factors Influencing Malaysian Consumers' Purchase Intention on Enviromental Friendly Lighting Products in Malaysia. Thesis. Universiti Sains Malaysia, Penang

Marquis, C, J Zhang dan Y Zhou, (2011). "Regulatory uncertainty and corporate responses to environmental protection in China", California Management Review, 54 (1): 39-63.

Mei, O.J., Ling K.C., \& Hooi, K.K. (2012). The Antecedents of Green Purchase Intention among Malaysian Consumers. IPEDR, $38,39-43$.

Mun, T.S. (2014). Factors That Influence Green Purchase Behaviour of Malaysian Consumers. Thesis. Faculty of Accountancy and Management, University Tunku Abdul Rahman.

Pavan, M. P. S. (2010). Green Marketing in India: Emerging Opportunities and Challenges. Journal of Engineering, Science and Management Education, 3, 914.
Piedmont R L. (1999). Does spirituality represent the sixth factor of personality? Spiritual transcendence and the five-factor model. Journal of Personality. 67, 9851014.

Rashid, N.A. (2009). Awareness of Ecolabel in Malaysia's Green Marketing Initiative. International Journal of Business and Management, 4(8), 132-141.

Ratnakar, R. \& Nair, S. (2012). A Review of Scientific Research on Spirituality. Business Perspective and Research, JulyDecember

Schultz, P. W., Shriver, C., Tabanico, J. J, \& Khazian, A. M. (2004). Implicit connections with nature. Journal of Environmental Psychology, 24(1), 31-42.

Tripathi, V., Shukla, S.M., Saran, P.K. \& Kumar, S. (2016). Purchase Intention Towards Eco-Friendly Electronic Products While Incorporating Mediating Influence of Brand Image. I J A B E R, 14(12) :83358348

Usmani, S., Kumari, K., Husain, J., Jamal, S. (2015). Consumer's Perception and Purchase Intention towards Green Product: Exploring The Attitude Among Pakistani Consumers. Abstract of SOCIONITS 15 